hope of all pioneers, and an insight of the untiring efforts and application necessary to the accomplishment of a modern detailed survey is given in his book "The Chart Makers" which, humorous though it is in many places, shows how arduous is the task of the surveyor and how painstaking his investigations.

In 1889, Somerville was appointed to the Surveying Ship Dart and served in her and in the Penguin in Australasian waters until 1896 ; after a short period of service in the Hydrographic Department, Admiralty, he joined the Egeria, and in that ship he proceeded to British Columbia, carrying out surveying work in the Straits of Magellan en route. During the latter part of the commission he became first lieutenant, and was in 1900 appointed first lieutenant of the Triton in home waters. He became commander in 1901 and was next appointed to take charge of special tidal observations in the Channel Islands. In 1903 , he was ordered to undertake special surveys in the Persian Gulf, for which he received the appreciation of the Lords of the Admiralty. In the early part of 1904 he was selected to take command of the Sealark to carry out surveys in the Mediterranean and East Indies; it was during his time in the Sealark that he was instructed to collaborate with the Percy Sladen Research Expedition, in the work of which he was already so interested. Returning home to England at the end of 1907, he was placed in charge of the West Coast of England Survey, and in 1912 took command of the Research in home waters, in which ship he was serving on the outbreak of war in 1914.

During the War, Somerville, who had been promoted to captain in 1908, was in command of H.M. Ships Victorian, Amphitrite, King Alfred and Devonshire in the 10th Cruiser Squadron. He was promoted to Rear-Admiral in 1919 and to ViceAdmiral (Retired) in 1925.

His last work in the Hydrographic Department was the compilation of "Ocean Passages of the World", and he served as chairman of a Tidal Com. mittee in 1923.

Admiral Somerville was interested in a great variety of subjects, and whilst in the Pacific Islands collaborated with the late Commander S. C. Weigall, R.N., in compiling vocabularies of dialects of some of the Polynesian islands; he also turned his mind to the improvement of sounding appliances, and the Somerville gear, which was a great advance on older methods of sounding, is still used in the survey . ing service. The last years of his life were devoted to literary work chiefly connected with the South Seas, where so much of his early life was spent. In 1934, he published "Commodore Anson's Voyage into the South Seas and Round the World", in which he used his knowledge of those waters to rewrite Walter's classic, embodying at the same time the results of his researches in the Admiralty records of the period. At the time of his death he was engaged on a similar modernised version of William Mariner's "Account of the Natives of the Tonga Islands", and had already collected a considerable amount of unpublished material not known to Dr. Martin, who published the original book in 1817 .

\section{Mr. C. A. W. Monckton}

WE regret to record the death, which took place on March 1 in London at the age of sixty-three years, of Mr. C. A. W. Monckton, explorer and formerly administrative official in Papua.

Charles Arthur Whitmore Monckton was born in New Zealand in 1872 and went to New Guinea in 1895, when Sir William MacGregor was Lieutenant. Governor. In 1898 he entered the public service as resident magistrate at Samarai. The administration of the country under British rule was then in its earliest stages of organisation, and Monckton's duties were largely the pursuit of raiding parties, who constantly attacked the white miners within his jurisdiction, which covered the north-eastern area of the island, not previously administered, and of which he was the first resident magistrate. In 1903 he was also given the Northern Division, which was in a state of disorder.

In 1906, when in pursuit of previously unvisited tribes, some of whose members had raided a miners' camp and murdered some of its occupants, Monckton made the first ascent of Mount Albert Edward $(13,320 \mathrm{ft}$.) under the fire of hostile bowmen, and mapped the country from it. A more strenuous expedition of the same year to the Wasia River in search of gold and to ascertain how far the river lay in British territory encountered terrible hardships and ended in disaster, for which Monckton was criticised by the authorities. In September 1906, New Guinea had come under the Australian Common. wealth; and Monckton, with characteristicimpetuosity, resigned and retired to England, where he lived for the remainder of his life.

A pioneer in administration, Monckton was one of the first to recognise that the qualities which lead a native to transgress the white code by adherence to tribal custom, such as raiding and head-hunting, might be turmed into useful channels. He invariably recruited his very efficient police from such criminals. $\mathrm{He}$ published three books in which a great gift of humour was used to advantage in displaying a keen appreciation of native character, while at the same time recording data of no little value relating to tribes at that time unknown. His first book, "Some Experiences of a New Guinea Resident Magistrate", appeared in 1920 and was received with acclamation by the critics. It was followed by "Last Days in New Guinea", published in 1922, and "New Guinea Recollections" in 1934.

WE regret to announce the following deaths :

Mr. James Whitehead, K.C., fellow of the Imperial College of Science and Technology, who was a leading authority on Patent law, especially in its applications to technology, on April 3, aged fifty-eight years.

Dr. W. A. Parr, president of the British Astro. nomical Association in 1932-34, on April 2.

Prof. J. Stoklasa, director of the State Institute of Research in Plant Products, Prague, on April 4, aged seventy-six years. 